\title{
Pendapatan ekonomi pemanfaatan sampah oleh pemulung di TPST Piyungan
}

\author{
Diananto Prihandoko ${ }^{1, *}$, Nasirudin ${ }^{2}$, Dedet Hermawan ${ }^{3}$ \\ ${ }^{1,2}$ Program Studi Teknik Lingkungan, Fakultas Teknik Lingkungan, Institut Teknologi Yogyakarta \\ ${ }^{3}$ Program Studi Teknik Elektro, Institut Teknologi Dirgantara Adisutjipto, Yogyakarta \\ Email Korespondensi: dito19@ity.ac.id
}

Received April 21, 2021; Revised May 23, 2021; Accepted May 24, 2021

\begin{abstract}
Abstrak
TPST Piyungan telah beroperasi sejak tahun 1995 dan mengalami penurunan kapasitas penampungan secara signifikan seiring pertumbuhan sampah di Kabupaten Bantul, Kabupaten Sleman dan Kota Yogyakarta. Hingga saat ini belum ditemukan alternatif penanganan sampah untuk menggantikan TPST Piyungan. TPST Piyungan juga mengalami masalah lain seperti pencemaran udara, kontaminasi air tanah oleh air lindi, dan kondisi sanitasi yang rendah. Namun demikian TPST Piyungan menjadi sumber mata pencaharian ratusan pemulung yang bekerja memulung sampah di zona aktif TPST Piyungan. Kajian ini bermaksud mengkaji pendapatan ekonomi pemulung TPST Piyungan. Sampel responden dipilih sebanyak 35 orang pemulung dengan menggunakan kriteria inklusi. Penelitian dilakukan dengan cara wawancara dan kueisioner. Hasil analisis menunjukkan bahwa 4 komponen terbesar sampah yang dikumpulkan oleh pemulung TPST Piyungan adalah plastik, kertas, botol kaca dan logam. Penghasilan dari penjualan sampah tersebut setiap bulan dapat mencapai Rp 2.028.000/orang. Keberadaan pemulung TPST Piyungan harus dijadikan salah satu pertimbangan bagi pemerintah dalam merumuskan alternatif penanganan sampah di masa yang akan datang.
\end{abstract}

Kata Kunci : pemulung; pendapatan ekonomi; TPA

\section{Abstract}

TPST Piyungan landfill has been operating since 1995 and its storage capacity has decreased significantly along with the growth of waste in Bantul Regency, Sleman Regency and Yogyakarta City. Until today, no alternative waste management has been implemented to replace TPST Piyungan. TPST Piyungan also experienced other problems such as air pollution, groundwater contamination by leachate, and poor sanitary conditions. However, the Piyungan TPST has become the source of livelihood for hundreds of waste pickers who work to collect garbage in the active zone of the TPST. The purpose of this study is to study the economic income of waste pickers at TPST Piyungan. 35 respondents were selected with purposive-sampling method using inclusion criteria. The research was conducted by interview and questionnaire. The results of the analysis show that the 4 biggest components of waste collected by waste pickers are plastic, paper, glass bottles and metal. The income from the sale of this waste can reach IDR 2,028,000 / person each month. The existence and livelihood of waste pickers at TPST Piyungan landfill must be one of the considerations for the government in formulating alternative waste management solutions in the future.

Keywords: waste pickers; economic income; landfill

\section{PENDAHULUAN}

TPST Piyungan yang terletak di Kabupaten Bantul DI Yogyakarta telah beroperasi sejak tahun 1995 dan menampung sampah dari 3 kabupaten/kota di provinsi DI Yogyakarta. Usia desain TPST Piyungan yang hanya 15-20 tahun menjadikan TPST ini seharusnya ditutup sejak tahun 2015, namun belum ditemukannya lahan pengganti menjadikan TPST Piyungan masih terus beroperasi hingga saat ini [1]. Timbulan sampah yang masuk ke TPST Piyungan pada tahun 2016 dan 2017 berturut-turut mencapai 504 dan 580 ton per hari [2]. Pertumbuhan timbulan sampah yang masuk ke TPST Piyungan mencapai $8 \%$ per tahun dan apabila tidak dilakukan upaya untuk mengurangi timbulan sampah, luas lahan yang diperlukan untuk menampung sampah akan meningkat 60 kali lipat pada tahun 2030 [3]. Masalah lain dalam pengelolaan TPST Piyungan adalah keberadaan hewan ternak sapi yang berjumlah ribuan yang memakan sampah di area TPST [2], adanya pencemaran udara berupa bau $\left(\mathrm{H}_{2} \mathrm{~S}\right)$ yang disebabkan oleh praktik pembuangan terbuka (open dumping) [4], adanya indikasi pencemaran air tanah di sekitar TPST Piyungan oleh air lindi [5] serta kondisi sanitasi lingkungan dan hygine yang masih rendah di sekitar TPST Piyungan yang berdampak pada kehidupan warga sekitar yang juga sebagian besar berprofesi sebagai pemulung [6]. 
Keberadaan pemulung di lokasi TPA sudah merupakan hal umum yang juga terjadi di seluruh dunia. Secara global terdapat lebih dari 15 juta orang yang menggantungkan hidup bekerja secara informal di sektor persampahan [7]. Pemulung sampah tergolong ke dalam sektor informal pengelolaan sampah, berbeda dengan sektor formal (pemerintah) dan sektor semi-formal (bank sampah dan TPS 3R) [8]. Sektor informal pengelolaan sampah yang terdiri atas pemulung dan pengepul sampah memainkan peranan penting dalam reduksi sampah. Reduksi sampah oleh sektor informal di Brazil rata-rata mencapai 9\% [9]. Di Kota Bandung Jawa Barat sebesar 13\% sampah yang dihasilkan masyarakat dapat diambil oleh pemulung [10]. Sedangkang di Yogyakarta, aktivitas pemulung di TPST Piyungan dapat mengurangi sampah hingga 5,03\% [11], reduksi tersebut hampir menyamai kemampuan reduksi sampah oleh seluruh bank sampah yang ada di Kota Yogyakarta, Kabupaten Bantul dan Sleman yang memiliki potensi reduksi sampah sebesar 7,7\% [12]. Walaupun memegang peranan penting dalam pengelolaan sampah, pekerja sektor informal pengelolaan sampah merupakan kelompok demografis rentan, sebagian besar pemulung merupakan perempuan, orang tua, anak-anak, pengangguran dan imigran. Mereka umumnya bekerja dalam kondisi yang tidak sehat, tidak memiliki jaminan sosial, memiliki tingkat pendidikan yang rendah, sering mendapatkan stigma sosial yang kuat serta pendapatan ekonomi yang sangat bergantung pada fluktuasi harga sampah [7].

Pendapatan ekonomi pemulung berasal dari penjualan sampah yang masih dapat didaur ulang (recycleables). Sampah yang diambil pemulung utamanya adalah plastik, kertas/kardus, logam, dan botol kaca serta kayu dan kain/tekstil dalam jumlah yang lebih sedikit [10]. Sebuah penelitian terhadap pendapatan pemulung di TPA Bantargebang Jakarta menunjukkan bahwa $80 \%$ pendapatan pemulung berasal dari penjualan plastik (plastik keras dan lunak), disusul logam berupa kaleng dan besi sebesar 3,7\%, botol kaca 2,7\%, aluminium $2 \%$, karet 1,6\% serta kertas $0,6 \%$ [13]. Rata-rata pendapatan rumah tangga pemulung TPA Bantargebang pada tahun 2013 adalah sebesar USD 216 per bulan atau setara dengan Rp 2.632 .824 per bulan, hampir setara dengan upah minum DKI Jakarta tahun 2013 [13]. Ditinjau dari segi ekonomi, sektor informal pengelolaan sampah dapat menciptakan lapangan kerja dan menghasilkan pendapatan ekonomi yang signifikan terutama, terutama bagi penduduk yang tidak dapat bekerja di sektor formal lain karena keterbatasan pendidikan dan keahlian [7].

Pengelolaan sampah di TPST Piyungan juga tidak terlepas dari adanya keberadaan pemulung yang menggantungkan kehidupan mereka dengan mengumpulkan sampah di zona aktif TPST. Kajian ini bertujuan untuk mengkaji pendapatan ekonomi pemulung yang berada di TPST Piyungan Yogyakarta. Kajian spesifik terbaru mengenai pendapatan ekonomi pemulung TPST Piyungan belum pernah dilakukan sehingga diharapkan kajian ini dapat memberikan data dan gambaran akurat dan terbaru mengenai pendapatan ekonomi pemulung di TPST Piyungan.

\section{METODE}

Kajian ini bersifat kuantitatif deskriptif yang menggambarkan data kuantitatif non-eksperimen terkait pendapatan ekonomi pemulung di TPST Piyungan. Data primer berupa volume dan jenis sampah yang dikumpulkan dan besar pendapatan per hari diperoleh dari nota penjualan pemulung dan wawancara langsung terhadap pemulung. Harga jual sampah diperoleh dari pengepul sampah yang berada di TPST Piyungan. Data sekunder berupa timbulan dan komposisi sampah yang masuk ke TPST Piyungan diperoleh dari pengelola TPST. Jumlah pemulung TPST Piyungan pada tahun 2017 adalah sebanyak 454 orang dan dari jumlah tersebut diambil sampel responden sebanyak 35 orang dengan metode purposive-sampling dan menggunakan kriteria inklusi sebagai berikut: bersedia menjadi responden, memiliki pengalaman memulung di TPST Piyungan minimal 3 tahun, berusia produktif kerja (17-50 tahun), dan pemulung yang mengambil sampah langsung di area TPST Piyungan. Pendapatan ekonomi pemulung dihitung dari volume penjualan sampah per hari kemudian dikalikan dengan rata-rata hari kerja untuk mengetahui pendapatan per bulan. Berikut adalah diagram alir penelitian:

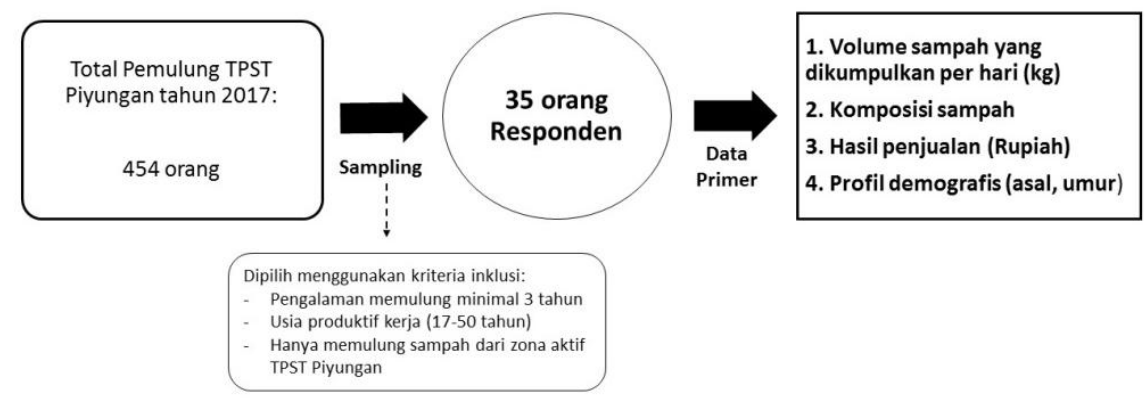

Gambar 1. Diagram alir metode penelitian 


\section{HASIL DAN PEMBAHASAN}

\subsection{Profil Demografis Pemulung TPST Piyungan}

Berdasarkan data Asosiasi Pemulung TPST Piyungan hingga tahun 2017 terdapat 454 orang pemulung yang bekerja mengumpulkan sampah di TPST Piyungan. Pemulung laki-laki berjumlah 243 orang (54\%) dan pemulung perempuan berjumlah 211 orang (46\%). Sebanyak 48\% pemulung berasal dari Kabupaten Bantul, 44\% berasal dari Kabupaten Gunungkidul, 1\% berasal dari Kota Yogyakarta, 6\% berasal dari berbagai kabupaten/kota di Jawa Tengah dan Jawa Timur dan sisanya berasal dari provinsi luar pulau Jawa. Total sebanyak 92\% pemulung TPST Piyungan berasal dari Kabupaten Bantul dan Gunungkidul karena TPST Piyungan terletak di Kabupaten Bantul bagian timur dan tidak jauh dari wilayah Kabupaten Gunungkidul.

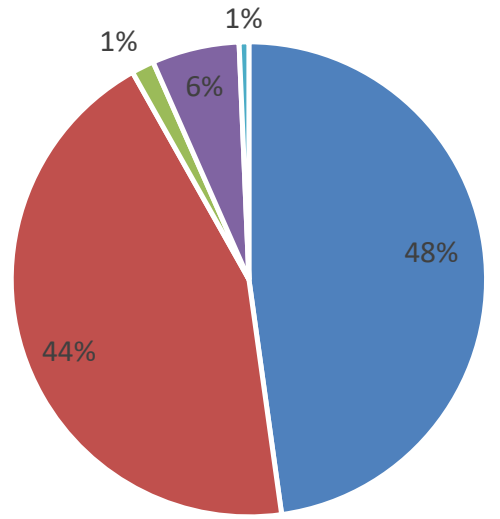

- Bantul

- Gunungkidul

- Kota Yogyakarta

- Jateng\&Jatim

- Luar Jawa

Grafik 1. Pengelompokan pemulung TPST Piyungan berdasarkan asal daerah (Paguyuban Pemulung TPST Piyungan, 2018)

Sebanyak 54\% pemulung telah bekerja lebih dari 10 tahun namun kelompok usia dengan jumlah terbanyak adalah pemulung pada kelompok usia 7-9 tahun yaitu sebanyak $26 \%$.

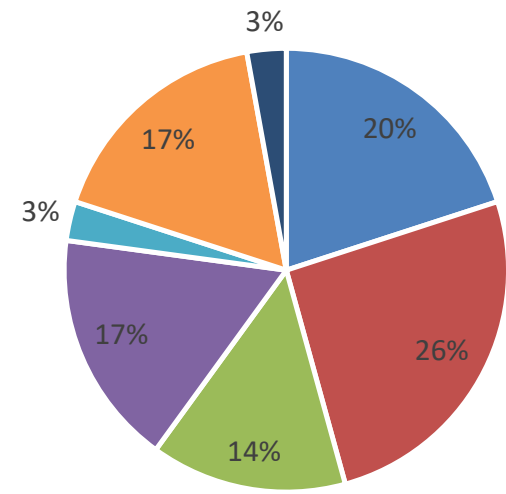

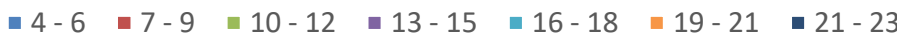

Grafik 2 . Klasifikasi pemulung TPST Piyungan berdasarkan lama bekerja sebagai pemulung (tahun)

(Paguyuban Pemulung TPST Piyungan, 2018) 
Sebanyak 20 orang responden adalah perempuan yang menyatakan bahwa mereka bekerja sebagai pemulung untuk membantu meningkatkan pendapatan ekonomi keluarga. Alasan utama para pemulung tetap bekerja di TPST Piyungan selama bertahun-tahun adalah untuk mendapatkan penghasilan ekonomi serta mereka merasa tidak memiliki banyak pilihan untuk mendapatkan pekerjaan di sektor formal yang memerlukan pendidikan dan pengalaman kerja.

\subsection{Pendapatan Ekonomi Pemulung TPST Piyungan}

Terdapat 4 jenis utama sampah dapat didaur ulang yang dikumpulkan oleh pemulung di TPST Piyungan yaitu: plastik, kertas, botol kaca dan logam. Total sampah rata-rata yang dapat diambil satu orang pemulung setiap hari mencapai $28 \mathrm{~kg}$ dengan komponen terbesar berdasarkan berat yaitu plastik, disusul botol kaca, kertas dan logam.

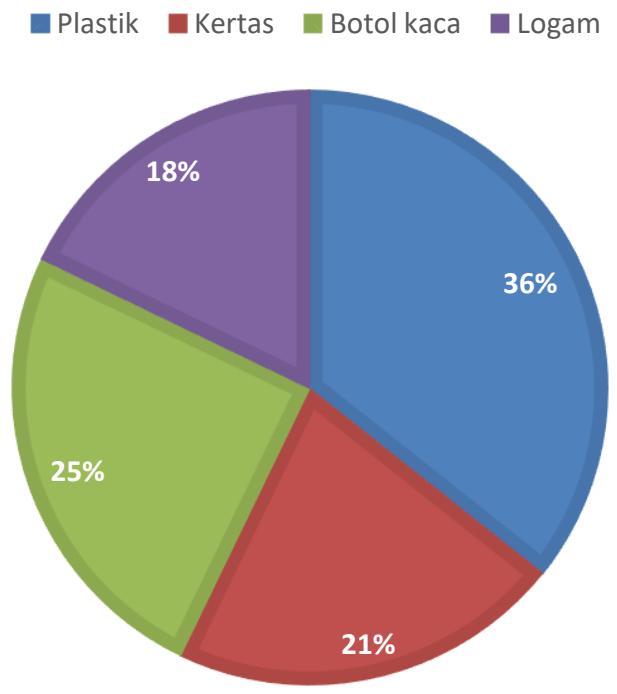

Grafik 3. Jenis sampah yang dikumpulkan oleh pemulung TPST Piyungan berdasarkan berat (Primer, 2018)

Harga beli sampah daur ulang bersifat fluktuatif namun rata-rata harga beli sampah per kilogram di TPST Piyungan pada tahun 2018 bagi plastik, kertas, botol kaca dan logam berturut-turut adalah Rp 4000, Rp 3500, Rp 500 dan Rp 4000. Pendapatan pemulung per hari dari penjualan sampah dapat dihitung dengan mengalikan volume sampah yang diperoleh per hari dengan harga beli sampah.

Tabel 1. Volume sampah yang dikumpulkan pemulung dan pendapatan per hari

\begin{tabular}{lccc}
\hline Jenis Sampah & Volume (kg/hari) & Harga beli (Rp/kg) & Penjualan (Rp) \\
\hline Plastik & 10 & 4.000 & 40.000 \\
Kertas & 6 & 3.500 & 21.000 \\
Botol kaca & 7 & 500 & 3.500 \\
Logam & 5 & 4.000 & 20.000 \\
$\quad$ Jumlah & 28 & & 84.500 \\
\hline
\end{tabular}

Apabila diasumsikan pemulung bekerja selama 6 hari dalam seminggu maka pendapatan yang dapat diperoleh selama 1 minggu dan 1 bulan dapat dihitung sebagai berikut

$$
\begin{array}{ll}
\text { Pendapatan per minggu } & =\operatorname{Rp~} 84.500 / \text { hari } \times 6 \text { hari } \\
& =\operatorname{Rp~507.000/orang/minggu~} \\
\text { Pendapatan per bulan } & =\operatorname{Rp~507.000/minggu~} \times 4 \text { minggu } \\
& =\operatorname{Rp~} 2.028 .000 / \text { orang/bulan }
\end{array}
$$

Keberadaan TPST Piyungan tidak diragukan lagi mendatangkan dampak ekonomi yang signifikan bagi masyarakat sekitar maupun pendatang yang bekerja sebagai pemulung. Hasil perhitungan menunjukkan bahwa pendapatan pemulung TPST Piyungan dapat mencapai Rp 2.028.000/bulan. Penghasilan tersebut sudah jauh 
melebihi besaran Upah Minimum Provinsi DI Yogyakarta tahun 2018 yang hanya sebesar Rp 1.454.154 [14]. Hasil analisis pendapatan menunjukkan bahawa kegiatan memulung sampah di TPST Piyungan dapat menghasilkan pemasukan yang lebih dari cukup untuk memenuhi kebutuhan hiduo. Sektor informal pengelolaan sampah mampu menciptakan lapangan kerja bagi jutaan orang di seluruh dunia yang kesulitan untuk mendapatkan pekerjaan karena tidak mempunya cukup pendidikan maupun keahlian [7]. Sektor informal sampah sebagian besar melibatkan kelompok sosial atau masyarakat kota yang termarginalisasi yang hanya mengandalkan aktivitas pemulung sebagai satu-satunya sumber pemasakan [15]. Namun demikian walaupun dapat mendatangkan pemasukan yang cukup tinggi relatif terhadap upah minimum, pemulung sampah di TPA bekerja dalam kondisi yang memprihatinkan dari segi sanitasi, keamanan dan kesehatan [13]. Peran aktif pemerintah sangat diperlukan dalam mengintegrasikan sektor informal sampah dalam kerangka besar pengelolaan sampah daerah, selain itu sumber penghidupan pemulung juga harus dijadikan pertimbangan dalam upaya peningkatan sistem manajemen atau teknologi pengolahan sampah [10]. Studi kasus yang dilakukan di beberapa negara selatan ekuator menunjukkan bahwa pemulung memainkan pernanan penting dalam penerapan circular economy, dimana sampah sebisa mungkin diminimalkan dan dimanfaatkan kembali, namun peran pemulung tersebut tidak diakui secara formal [16].

Usia desain TPST Piyungan yang telah berakhir serta kapasitas penampungan yang semakin menurun akan memaksa pemerintah provinsi DI Yogyakarta dan pemerintah daerah Kabupaten Bantul, Sleman dan Kota Yogyakarta untuk menemukan alternatif baru penanganan sampah, baik dengan mencari lahan untuk TPA baru ataupun menerapkan teknologi pengolahan sampah seperti PLTSa. Diperlukan adanya sebuah pendekatan baru dalam pengelolaan sampah TPST Piyungan, salah satunya dengan pendekatan paradigma wastepreneurship pengelolaan sampah, melalui paradigma ini kegiatan pengelolaan sampah dipandang dapat menciptakan nilai ekonomi, salah satunya dengan penerapan teknologi Waste-to-Energy insinerator dengan tetap melibatkan pemulung untuk mengurangi sampah yang masih dapat didaur ulang. 70\% warga sekitar TPST Piyungan yang sebagian besar berprofesi sebagai pemulung sepakat dengan adanya penerapan teknologi lanjutan pengolahan sampah di TPST Piyungan, dengan syarat mereka tetap diperbolehkan untuk memulung sampah [17]. Apapun alternatif yang dipilih, pemerintah harus mempertimbangkan keberadaan lebih dari 400 orang pemulung yang bekerja menggantungkan hidup memulung sampah di TPST Piyungan karena adanya alternatif penanganan baru dapat berpotensi mengurangi atau bahkan menghilangkan sumber pemasukan pemulung.

\section{KESIMPULAN}

Potensi pendapatan ekonomi yang dapat diperoleh oleh pemulung di TPST Piyungan mencapai Rp 2.028.000/orang/bulan. Pendapatan tersebut jauh melampaui Upah Minimum Provinsi D.I Yogyakarta yang menandakan bahwa aktivitas memulung sampah di TPST Piyungan dapat mendatangkan pendapatan yang signifikan. Di sisi lain para pemulung masih hidup dan beraktivitas dalam kondisi sanitasi yang buruk dan berpotensi bahaya. Keberlanjutan operasional TPST Piyungan di masa yang akan datang juga akan berpengaruh terhadap pendapatan pemulung. Apabila pemerintah akan merumuskan solusi baru penanganan sampah sebagai alternatif TPST Piyungan, keberlangsungan hidup pemulung harus menjadi salah satu bahan pertimbangan mengingat jumlah pemulung mencapai ratusan orang yang menggantungkan hidup di TPST Piyungan.

\section{DAFTAR PUSTAKA}

[1] Ariyani, Safira Firda, et al. "Evaluation of Waste Management in Piyungan Landfill, Bantul Regency, Yogyakarta, Indonesia." MATEC Web of Conferences. Vol. 280. EDP Sciences, 2019.

[2] DLH Bantul. Penyusunan Laporan Akhir Dokumen Valuasi Lingkungan Operasional TPST Piyungan. Dinas Lingkungan Hidup Kabupaten Bantul. Bantul. (2018)

[3] Sudibyo, Hanifrahmawan, et al. "Municipal solid waste management in Indonesia-A study about selection of proper solid waste reduction method in DI Yogyakarta Province." Energy Procedia 143 (2017): 494-499.

[4] Karimuna, Siti Rabbani. "Faktor-Faktor Yang Berhubungan Dengan Kualitas Udara Dalam Rumah Di Sekitar Tempat Pembuangan Akhir Sampah Desa Sitimulyo Kecamatan Piyungan Kabupaten Bantul Tahun 2012”. Diss. [Yogyakarta]: Universitas Gadjah Mada, 2013.

[5] Harjito, Harjito, et al. "Underground Leachate distribution based on electrical resistivity in Piyungan Landfill, Bantul." Indonesian Journal of Geography 50.1 (2018): 34-40. 
[6] Munandar, Jasas, and Surahma Asti Mulasari. "Environmental Sanitation and Hygiene on Waste Collector in TPA Piyungan Bantul Yogyakarta." KEMAS: Jurnal Kesehatan Masyarakat 15.2 (2019): 171-178.

[7] Kaza, Silpa, et al. What a waste 2.0: a global snapshot of solid waste management to 2050. World Bank Publications, 2018.

[8] Putra, Hijrah Purnama, Enri Damanhuri, and Emenda Sembiring. "Sektor Baru Pengelolaan Sampah Di Indonesia (Studi Kasus Di Kota Yogyakarta, Kabupaten Sleman Dan Bantul)." Jurnal Sains \& Teknologi Lingkungan 11.1 (2019): 11-24.

[9] Marello, Marta, and Ann Helwege. "Solid waste management and social inclusion of wastepickers: opportunities and challenges." Latin American Perspectives 45.1 (2018): 108-129.

[10] Sembiring, Emenda, and Vilas Nitivattananon. "Sustainable solid waste management toward an inclusive society: Integration of the informal sector." Resources, Conservation and Recycling 54.11 (2010): 802-809.

[11] Muli, N. Peran serta pemulung dalam pengurangan sampah di TPA Piyungan Daerah Istimewa Yogyakarta. Diss. Tesis Program Studi Magister Teknik Sistem, Yogyakarta, 2016.

[12] Putra, Hijrah Purnama, Enri Damanhuri, and Emenda Sembiring. "Integration of formal and informal sector (waste bank) in waste management system in Yogyakarta, Indonesia." MATEC Web of Conferences. Vol. 154. EDP Sciences, (2018).

[13] Sasaki, Shunsuke, et al. "Household income, living and working conditions of dumpsite waste pickers in Bantar Gebang: Toward integrated waste management in Indonesia." Resources, conservation and recycling 89 (2014): 1121.

[14] BPS DIY. Upah Minimum Kabupaten/Upah Minimum Provinsi di DI Yogyakarta (Rupiah), 2018-2020. BPS Provinsi DI Yogyakarta. https://yogyakarta.bps.go.id/indicator/6/272/1/upah-minimum-kabupaten-upah-minimum-provinsi-didi-yogyakarta.html diakses pada tanggal 29 Maret 2021

[15] Ackerman F, Mirza S. Waste in the inner city; asset or assault? Local Environment. 2001;6:113-20.

[16] Gutberlet, Jutta, et al. "Waste picker organizations and their contribution to the circular economy: Two case studies from a global south perspective." Resources 6.4 (2017): 52.

[17] Prihandoko, D., Budiman, A., Fandeli, C., Setyono, P. A New Paradigm for Solid Waste Management in Integrated Waste Management Site Piyungan Yogyakarta Indonesia. Applied Mechanics and Materials, Vol. 898. (2020): 51-57. 